\title{
Стабилизация волоконного фемтосекундного синтезатора частот по оптическому стандарту частоты на основе одиночного иона иттербия
}

\author{
Н.А. Коляда ${ }^{1, *}$, В.С. Пивцов ${ }^{1,2}$, А.С. Дычков ${ }^{1}$, С.А. Фарносов ${ }^{1}$, \\ С.А. Кузнецов ${ }^{1}$, А.А. Филонов ${ }^{1}$, Д.Ю. Примаков ${ }^{1}$ \\ ${ }^{1}$ Институт лазерной физики СО РАН \\ ${ }^{2}$ Новосибирский государственный технический университет \\ "E-mail: n.koliada@mail.ru
}

DOI: $10.31868 /$ RFL2020.75-76

Фемтосекундный синтезатор частот является одной из основных частей фемтосекундных оптических часов (ФОЧ) [1 - 2]. ФОЧ позволяют исследовать фундаментальные физические процессы, измерять частоту переходов атомов и молекул, на их основе разрабатываются системы для увеличения точности спутниковой навигации и т.д. Современные ФОЧ включает в себя три основные части - опорный оптический стандарт частоты, фемтосекундный синтезатор, частоты которого стабилизируются по опорному стандарту и радиоэлектронная система стабилизации.Фемтосекундный синтезатор генерирует эквидистантную частотную гребенку. Каждая частота этой гребенки выражается суммой $f_{n}=f_{o}+$ $n \cdot f_{\text {rep }}$, где $f_{o}$ - частота смещения гребенки, $f_{\text {rep }}-$ частота повторения импульсов (межмодовая частота), $n$ - целое число [3]. Стабилизировав каким-либо способом две из этих трех частот, можно получить гребенку оптических и радиочастот, каждая компонента которой будет обладать относительной стабильностью опорного оптического стандарта.

В данной работе экспериментально исследовалась возможность прецизионной стабилизации фемтосекундной гребенки оптических частот, генерируемой с помощью фемтосекундного эрбиевого волоконного лазера, по оптическому стандарту частоты на основе одиночного иона иттербия [4]. При этом частота смещения гребенки $f_{o}$ детектировалась с помощью двуплечевого $f$ - $2 f$ интерферометра [5] и стабилизировалась с помощью внерезонаторного акустооптического частотного модулятора (АОЧМ) с волоконными выводами. Данный подход позволил увеличить полосу стабилизации частоты смещения до нескольких десятков кГц. С помощью оптического смесителя была получена частота биений $f_{b}$ между частотой выходного излучения $\mathrm{Yb}^{+}$стандарта (на длине волны 871 нм) и ближайшей к ней удвоенной по частоте компоненты фемтосекундной гребенки (на длине волны 1742 нм). Полученный сигнал биений стабилизировался с помощью внутрирезонаторного электрооптического модулятора на основе кристалла КТР [6].Таким способом были стабилизированы все компоненты фемтосекундной гребенки частот. Преимуществом предложенного метода является то, что отработка высокочастотных возмущений двух сигналов с помощью внутрирезонаторного ЭОМ и внерезонаторного АОЧМ практически не влияет друг на друга. Такой подход позволил осуществить стабилизацию фазочастотных возмущений в полосе 200 кГц для $f_{b}$ с помощью ЭОМ и в полосе 230 кГц $f_{o}$ с помощью АОЧМ. Полоса отработки с помощью АОЧМ ограничена рабочей полосой радиоэлектронной системы стабилизации и конфигурацией АОЧМ, и может быть увеличена.

Были проведены исследования нестабильности выходных радиочастот волоконного фемтосекундного синтезатора. Для реализации схемы измерения дополнительно к волоконному фемтосекундному синтезатору был использован 
фемтосекундный синтезатор на основе Ti:Sa лазера, разработанный ранее в Институте лазерной физики СО РАН. Каждый из синтезаторов стабилизировался по частотам двух различных лазерных систем входящих в состав оптических стандартов на основе одиночного иона иттербия. В обоих синтезаторах детектировался сигнал межмодовых биений на частоте 3 ГГц. С помощью радиочастотного смесителя был получен разностный сигнал на частоте 10 МГц. Полученный разностный сигнал после фильтрации регистрировался с помощью измерителя фазовых шумов MicrosemiTSC-5120A. Данный прибор сравнивает по фазе опорный и исследуемый сигнал. В качестве опорного сигнала использовался сигнал от водородного стандарта пассивного типа (ЗАО «Время-Ч») с частотой 10 МГц. Из полученных данных был рассчитан параметр Аллана, характеризующий суммарную относительную нестабильность двух фемтосекундных синтезаторов. Получены значения близкие к значениям нестабильности лазерных систем оптических стандартов.

Работа была проведена с использованием оборудования ЦКП "Фемтосекундный лазерный комплекс" при ИЛФ СО РАН. Исследования выполнены при финансовой поддержке программы фундаментальных научных исследований СО РАН № II.11.1.

\section{Литература}

[1] S.N. Bagayev, V.I. Denisov et al, Laser Phys.14, 1367 -1374 (2004)

[2] S.A. Diddams, Th. Udem et al, Science 293, 825 - 828 (2001)

[3] H.R. Telle, G. Steinmeyer et al, Appl. Phys. B 69, 327-332 (1999)

[4] S.V. Chepurov, A.A. Lugovoy et al, Quantum Electronics 49, 412-417 (2019)

[5] M.C. Stumpf, S. Pekarek et al, Appl. Phys. B 99, 401-408 (2010)

[6] N.A. Koliada, B.N. Nyushkov et al, Quantum Electronics 46, 1110-1112 (2016) 